\title{
Women in Board of Directors and Real Earnings Management: Accretive Share Buyback in Malaysia
}

\author{
Abdulsalam Saad Alquhaif \\ ${ }^{\mathrm{A}} \mathrm{PhD}$ Candidate, College of Business \\ Tunku Puteri Intan Safinaz School of Accountancy (TISSA) \\ Universiti Utara Malaysia, 06010 Sintok, Kedah, Malaysia \\ ${ }^{B}$ Faculty of Business and Accounting, IBB University \\ Tel: 60-19-245-5907Ｅ-mail: alquhif20@gmail.com
}

\begin{abstract}
Rohaida Abdul Latif
Associated Professor, College of Business,

Tunku Puteri Intan Safinaz School of Accountancy (TISSA)

Universiti Utara Malaysia, 06010 Sintok, Kedah, Malaysia

Tel: 60-4-928-7310 E-mail: roaida@uum.edu.my

Sitraselvi Chandren

Senior Lecturer, College of Business,

Tunku Puteri Intan Safinaz School of Accountancy (TISSA)

Universiti Utara Malaysia, 06010 Sintok, Kedah, Malaysia

Tel: 60-4-928-7328Ｅ-mail: sitraselvi@uum.edu.my
\end{abstract}

Received: July 3, 2017 Accepted: August 2, $2017 \quad$ Published: December 1, 2017

doi:10.5296/ajfa.v9i2.11752 URL: https://doi.org/10.5296/ajfa.v9i2.11752

\section{Abstract}

Gender diversity of boards and reporting of earnings are two most debated issues in the 
corporate world. In this context, the paper explores how the presence of women directors on the corporate board influence real earnings management through accretive buyback programs. Using a sample of 601 firms' observations that engage in accretive share buyback from 2010-2015, the findings reveal that existence of women directors on the board is associated with less engagement in accretive share buyback activities. We further find that firms with a higher number of independent directors are less likely to practice real earnings management through accretive buyback programs. Our paper contributes to the debate on gender diversity on boards and its influence on the utilisation of accretive buyback programs as a tool to real earnings management.

Keywords: Women directors, Board of directors, Real earnings management, Accretive share buyback, Malaysia 


\section{Introduction}

In the recent decades, gender diversity on top corporate positions has attracted rising attention subsequently to financial scandals and legislative reforms. Since researchers have focused on the pattern of appointing women as directors on the board or as executives, Researchers find women's participations on top management level varies across countries. Existing literature reveals that women on boardrooms are under-represented despite their high participation in the workforce (Amran et al., 2014). Malaysian authorities in 2004 have required the public-sector agencies to increase the representation of women on decision-making level to reach 30 percent. Subsequently, the governance in 2011 protracted the policy and involve the private sector in the strategy of represented-women to increase the existing of women on the top management and identify the year 2016 as the date to match the target 30 percent (The Star, June 27, 2011).

Deloitte (2015) has provided a professional report for gender diversity on board of directors worldwide. Norway and France have the highest women representative on the board which accounted about 36.7 and 29.9 percent respectively. Japan has the lowest percentage of women held seats on board which was about 2.4 percent. Regarding Malaysia, Deloitte's report (2015) reveals that women represented about 10.4 percent of board seats, which is slightly less than the average of world rate, which is 12 percent. Recently, in April 2016 FMT state report on women participation on the boardrooms, which reveals that the presence of women in top management increase from 8.3 percent to 12.5 percent during 2014 . The report also shows that Malaysia is the second country after Australia 21.9 percent in women nominated on board of directors (FMT, April 20, 2016).

The literature on boards' gender diversity commonly supports the argument that representation of women on the board enhances firm's financial performance (S. M. Adams, Gupta, \& Leeth, 2009; Campbell \& Mínguez-Vera, 2008; Lam, Mcguinness, \& Paulo, 2013). Regarding board of directors' effectiveness, prior studies indicate an effective role for gender diversity in enhancing monitoring tasks and improving decisions quality (R. B. Adams \& Ferreira, 2009; Nielsen \& Huse, 2010; Valenti, 2008). Regarding earnings management, previous studies of Gavious, Segev and Yosef (2012), Peni and Vähämaa (2010) and Krishnan and Parsons (2008), provide evidence that firms with a higher number of women on the board are less likely to manipulate earnings. Recently, Arun, Almahrog and Ali Aribi (2015) find that firms with a higher number of women and independent women directors are adopting restrained earnings management practices.

According to prior studies, managers have several incentives to manage earnings; to maximise stock price prior to security issuance (Graham, Harvey, \& Rajgopal, 2005; S. H. Teoh, Welch, \& Wong, 1998; S. Teoh, Welch, \& Wong, 1998) to meet analyst forecasts (Sitrasellvi Chandren, 2016; Gunny, 2010; Skinner \& Sloan, 2002), and to increase managerial compensation (Cheng \& Warfield, 2005; Healy, 1985). Recent literature reveals that managers using firms' real activities to manipulate earnings, which directly affect cash flows (Cohen, Dey, \& Lys, 2008; Roychowdhury, 2006; Sun, Lan, \& Liu, 2014). Managers also employ share buyback activities as a tool for managing reported EPS through adjusted 
outstanding shares that represent denominators of EPS equation (Burnett, Cripe, Martin, \& McAllister, 2012; Hribar, Jenkins, \& Johnson, 2006). Based on these different views, this paper examines the association between women directors and real earnings management through accretive share buyback in Malaysia.

Our paper contributes to the existing literature by focusing on the women serving on the board of directors as a determinant of accretive buyback activities during the scope of Malaysian Code of Corporate Governance (MCCG 2012). Previous studies focus on influence of some firms' financial characteristics (Farrell, Unlu, \& Yu, 2014) and some governance features such as board of directors, audit quality and managerial ownership (S Chandren, Ahmad, \& Ali, 2015; Farrell, Yu, \& Zhang, 2013; Farrell et al., 2014). The findings of this paper may help policy makers and regulators to draw policy implications on the importance of existing women on the top management, where the results reveal the efficacy of women on boardrooms especially in emerging market. It also supports the orientation of policy makers to increase gender diversity on the top level of decision making. The paper is organised as follows. The development hypothesis of women directors and earnings management are set out in Section 2. Section 3 discusses the empirical research methods used. Section 4 shows the findings and discussions and Section 5 displays the conclusion.

\section{Hypotheses Development}

Previous studies report that women are more ethical in the workplace and less likely to engage in unethical behaviour to gain financial rewards (Betz \& Skepard, 1989; Khazanchi, 1995). They argue that The existence of female directors on top management level reduce information asymmetry between women directors and managers through obtaining voluntary information as well as better to demonstrate greater ethical behaviour and risk aversion (Francis, Hasan, Park, \& Wu, 2009; Gul, Yu, Fung, \& Jaggi, 2009). Byrnes, Miller, and Schafer (1999) provide evidence that women are less likely to take risks, particularly in the financial decision environment. Further, Arun et al. (2015) and Powell and Ansic (1997) indicate that women on top management are more cautious and less aggressive than men in a variety of decision-making contexts.

Regarding earnings management, prior studies reveal that the quality of earnings is higher for firms with more women directors (Krishnan \& Parsons, 2008; Peni \& Vähämaa, 2010; Thiruvadi \& Hua-Wei Huang, 2011). Further, Gavious et al. (2012) and Barua, Davidson, Rama, and Thiruvadi (2010) reveal that firms with women CEOs have fewer earnings management than those with males, and document a negative relationship between women executives and earnings management. Liu, Wei, \& Xie (2016) provide evidence that that man CFOs to save their job they aggressively engage in earnings management more than women CFOs, suggesting that women CFOs are more conservative in financial reporting than their counterparts from men as well as less involved in earnings management. Based on this view, we hypothesise that:

Firms with women directors on the board are less likely to engage in real earnings management through an accretive share buyback. 


\section{Methodology}

\subsection{Sample}

Following Hribar et al. (2006), we measure the accretive share buyback as a real earnings management model. He establishes two steps to distinguish between accretive and non-accretive buyback activities; Firstly, we begin to remove the impact of buyback activities from EPS by computing EPS without shares buyback which is called ASIF EPS. The paper calculates ASIF_EPS by estimating the denominator and numerator effects of accretive shares buyback on EPS as follows:

$$
\text { ASIF_EPS }=\mathrm{NI}_{\text {it }} /\left(\text { Shares outstanding }_{\text {it }}+0.5 \times \text { Shares issued }{ }_{i t}\right)
$$

Where ASIF_EPS represents the estimated EPS in the absence of accretive share buybacks, $\mathrm{NI}_{\text {it }}$ is reported earnings before comprehensive income available to ordinary shareholders for fiscal year, Shares outstanding it is the reported number of ordinary shares outstanding, at the beginning of the firm year, Shares issued ${ }_{\text {it }}$ is the actual or estimated number of ordinary shares issued during a year. The second step is to compute the difference between reported EPS as presented in financial statement and EPS without shares buyback impact (ASIF EPS). If the difference between them is a positive value, it is an accretive shares buyback. Based on prior studies such Burnett et al. (2012), Farrell et al. (2014) and Hribar et al. (2006), shares buyback is accretive shares buyback when it leads to change in EPS by one cent.

The total number of Malaysian listed firms that engaged in accretive share buyback from 2010 to 2015 is 106 firms based on the Hribar' model. As displayed in Table 1, we excluded financial listed firms because they apply different regulatory requirements. Further, we excluded firms with incomplete data or missing annual report from the sample selected. These processes yield an ultimate sample consisting of 601 firm year observations with 225 observations of accretive share buybacks (39.1\% of the sample) and 374 none-accretive share buybacks $(60.9 \%$ of the sample). The information on accretive share buyback, women directors, independence and size of the board, and Big 4 audit firms are obtained from the annual reports available on the Bursa Malaysia website. Whereas the other control variables, ROE, FSIZE, LEV and FCF showed in the model below are collected from Thomson DataStream. The actual annual EPS data for a year from 2010 - 2015 were obtained from the annual reports on Bursa Malaysia websites.

Table 1. Sample selection process during the Sample Period

\begin{tabular}{lc}
\hline Calculation of 601 observations: & Firms year observations. \\
\hline Accretive buyback firms 2010-2015 & 106 \\
Less: Financial accretive buyback & 5 \\
Non-financial accretive buyback firms & 101 \\
Accretive buyback firm's observations (101 firms *6 & 606 \\
years) & \multicolumn{2}{c}{2} \\
Less: firms' observations without prior years' data & 3 \\
Less: unlisted firms' observations in 2015 & 601 \\
Total observations for accretive buybacks firms & \multicolumn{2}{c}{ ajfa.macrothink.org }
\end{tabular}




\subsection{Empirical Models}

This paper utilised logistic regression since the dependent variable (ABBD) is a dichotomous variable. Based on previous studies, this paper uses the following model to examine the proposed hypothesis.

$$
\begin{gathered}
\mathrm{ABBD}=\beta_{0}+\beta_{1} \text { GENDER }+\beta_{2} \mathrm{BIND}+\beta_{3} \mathrm{BSIZE}+\beta_{4} \mathrm{BIG} 4+\beta_{5} \mathrm{ROE}+\beta_{6} \text { FSIZE }+\beta_{7} \mathrm{LEV} \\
\mathbf{t} \mathbf{- 1}+\beta_{8} \mathrm{FCF}_{\mathbf{t}-\mathbf{1}}+\mathrm{e}
\end{gathered}
$$

Where

ABBD A dichotomous variable equal 1 for accretive share buyback; 0 otherwise.

GENDER A dichotomous variable equal to one if board of directors contain at least one women, and zero otherwise;

BIND Percentage of independent directors serving on board of directors scaled by the board size;

BSIZE The number of directors serving on board of directors;

BIG4 A dichotomous variable equal to one if the firms audited by one of Big4 audit firms, and zero otherwise;

ROE the net income scaled by shareholders' equity

FSIZE $_{\mathrm{t}-1} \quad$ Natural log of total assets at the beginning of the year.

$\mathrm{LEV}_{\mathrm{t}-1}$ The ratio of current plus long-term debt to total assets at the beginning of the year.

FCF $_{\text {t-1 }} \quad$ The ratio of firm's beginning of the year cash and cash equivalents scaled by total assets.

\section{Findings and discussions}

\subsection{Descriptive Statistics and Univariate Tests}

The descriptive statistics for the women serving on the board variable as well as for the other control variables are presented in Table II. The table shows the statistics for the entire sample of 601 observations. The statistics demonstrate that nearly 48 percent of the sample firms contain women serving on their boardroom during the sample period 2010-2015. Accordingly, independent directors represent 45 percent of board size which is consistent with the recommendation of MCCG 2012. The table also reveals that Big 4 audit firms audit about 50 percent of the sample firms. 
Table 2. Descriptive statistics of independent Variables.

\begin{tabular}{|c|c|c|c|c|c|}
\hline Variables & Mean & Median & Std. Dev. & Min & Max \\
\hline \multicolumn{6}{|c|}{ Number Obs. $=601$} \\
\hline ABBD & 0.3910 & 0 & 0.4883 & 0 & 1 \\
\hline GENDER & 0.4792 & 0 & 0.4999 & 0 & 1 \\
\hline BIND & 0.4544 & 0.4285 & 0.1202 & 0.1667 & 1 \\
\hline BSIZE & 7.4309 & 7 & 1.9754 & 4 & 14 \\
\hline BIG4 & 0.5024 & 1 & 0.5004 & 0 & 1 \\
\hline ROE & 0.0999 & 0.0842 & 0.3342 & -1.1469 & 7.4308 \\
\hline FSIZE $(\log )$ & 19.993 & 19.763 & 1.6103 & 16.7523 & 24.834 \\
\hline LEV & 0.1813 & 0.1649 & 0.1446 & 0 & 0.7601 \\
\hline FCF & 0.1622 & 0.1201 & 0.1408 & -0.0378 & 0.8801 \\
\hline
\end{tabular}

The following Table 3 shows the Pearson correlation results of independent and control variables. Results in Table 3 show low coefficient correlations which indicate that less serious multicollinearity problems between independent variables, where the highest correlation is 54 percent which is between FSIZE and LEV.

Table 3. Correlation matrix of variables

\begin{tabular}{|c|c|c|c|c|c|c|c|c|c|}
\hline Variables & ABBD & GENDER & BIND & BSIZE & BIG4 & ROE & FSIZE & LEV & FCF \\
\hline ABBD & 1 & & & & & & & & \\
\hline GENDER & -0.038 & 1 & & & & & & & \\
\hline BIND & $-0.090^{*}$ & $-0.26^{* * *}$ & 1 & & & & & & \\
\hline BSIZE & 0.065 & $0.28 * * *$ & $-0.36^{* * *}$ & 1 & & & & & \\
\hline BIG4 & -0.021 & 0.009 & $-0.15^{* *}$ & $0.09^{*}$ & 1 & & & & \\
\hline ROE & -0.003 & -0.07 & -0.058 & 0.019 & 0.072 & 1 & & & \\
\hline FSIZE & 0.047 & $0.13 * *$ & -0.056 & $0.45^{* * *}$ & $0.35^{* * *}$ & 0.092 & 1 & & \\
\hline LEV & -0.028 & $0.22^{* * *}$ & $-0.19 * * *$ & $0.33 * * *$ & $0.14 * *$ & -0.027 & $0.55^{* * *}$ & 1 & \\
\hline $\mathrm{FCF}$ & 0.034 & $-0.09 *$ & 0.028 & -0.08 & -0.060 & 0.098 & $-0.18 * * *$ & $-0.3^{* * *}$ & 1 \\
\hline
\end{tabular}

Notes: $* * *, * * *$ significant at $10 \%, 5 \%$, and $1 \%$ levels, respectively.

\subsection{Multivariate Analysis}

The results of panel logistic regression are presented in Table 4, which provide considerable evidence regarding the tested hypothesis of our paper. As shown in in the table, the coefficient on the percentage of women serving on the board of directors (GENDER) is -0.3007 which is significantly negative accretive share buyback $(z=-1.65, p<0.10)$. The findings are somewhat consistent with our prediction that the presence of women directors on firms' board of directors is less likely to utilise accretive share buyback to manage EPS. The result is also slightly consistent with the argument that women are more conservative and less risk tolerance than a man in making decisions related to managing earnings (Ittonen \& Peni, 2012; Krishnan \& Parsons, 2008; Peni \& Vähämaa, 2010). Practically, the results of this 
paper support the policy of the Malaysian government to increase the presence of women in decision-making positions to become 30 percent in both public and private sectors.

The findings reveal the association between women on the board of directors and accretive buyback is significant only at 0.10 , which support the outcomes of the reports that reveal the presence of women in the top management in Malaysia is still under normal level (Delliotte, 2015; FMT, 2016). Regarding control variables, the result also reported a negatively significant association between accretive share buyback (earnings management proxy) and board of directors independent (BIND) with $\mathrm{t}=-2.65$ and coefficient at -2.1467 , which is consistent with Siagian and Tresnaningsih (2011) and Xie et al. (2003) who found effective role of the board independence in constraining earnings management. This empirical evidence hence supports the role of independent directors as an effective mechanism in monitoring managers' behaviours.

However, BSIZE and BIG4 variables have no significant association with accretive share buyback actions. Consistent with Abdul Latif and Taufil-Mohd (2013), free cash flow (FCF) has an insignificant relationship which means accretive share buyback activities do not influence by excess cash flow. Whereas, firm size $(z=2.1, p=0.036)$ is significantly positive, indicating that large firms are more likely to manage earnings through an accretive share buyback. Finally, the table shows a significantly negative linkage among firms' leverage and accretive buyback, suggesting high leverage firms are less likely to increase EPS by share buyback activities, or firms may use share buyback programs to reach the optimal capital structure (Dittmar, 2000).

Table 4. Result of multivariate logistic regression

\begin{tabular}{llcll}
\hline $\begin{array}{l}\text { Independent } \\
\text { Variables }\end{array}$ & Coefficient & Std. Err. & z & P.value \\
\hline Constant & -2.3002 & 1.2869 & -1.99 & $0.047^{* *}$ \\
GENDER & -0.3007 & 0.1825 & -1.65 & $0.099^{*}$ \\
BIND & -2.1467 & 0.8098 & -2.65 & $0.008^{* *}$ \\
BSIZE & 0.02866 & 0.0526 & 0.54 & 0.586 \\
BIG4 & -0.2751 & 0.1857 & -1.48 & 0.139 \\
ROE & -0.18595 & 0.3043 & -0.57 & 0.568 \\
FSIZE & 0.15530 & 0.0741 & 2.1 & $0.036^{* *}$ \\
LEV & -1.40112 & 0.7659 & -1.83 & $0.067^{*}$ \\
FCF & 0.35498 & 0.6402 & 0.55 & 0.579 \\
Log likelihood & \multicolumn{5}{c}{-394.229} & \\
LR chi2(8) & 15.92 & & \\
No Obs. & 601 & \\
\hline
\end{tabular}

Notes: $*, * *, * * *$ significant at $10 \%, 5 \%$, and $1 \%$ levels, respectively. ABBD is a dichotomous variable equal 1 for accretive share buyback; 0 otherwise.; GENDER is A dichotomous variable equal to one if board of directors contain at least one women, and zero otherwise; BIND is a percentage of independent directors serving on the board of directors; BSIZE is the number of directors serving on the board; BIG4 is a dichotomous variable equal to one if firm is audited by Big4 auditors, and zero 
otherwise; $\mathrm{ROE}_{\mathrm{t}-1}$ is return on equity at the beginning of the year ;FSIZE ${ }_{t-1}$ is the logarithm of the firm's total assets at the beginning of the year; $\mathrm{LEV}_{\mathrm{t}-1}$ is total debt at the beginning of the year, deflated by total assets; $\mathrm{FCF}_{\mathrm{t}-\mathrm{1}}$ is cash and cash equivalent at the beginning of the year, deflated by total assets.

\section{Conclusions}

The purpose of our paper is to examine the nature of shares buyback activities between Malaysian listed firms for the years 2010-2015 and to examine whether the existence of women directors on the board is associated with activities of earnings management through an accretive share buyback. Using a sample of 601 firms' observations that engage in accretive share buyback from 2010-2015, the findings reveal that existing of women directors serving on the board are associated with less likelihood of accretive share buyback activities. The outcome shows that women directors are effective in monitoring managers' actions, especially regarding earnings management practices. Our results thus are consistent with previous studies proving the effective monitoring by women directors (Krishnan \& Parsons, 2008; Peni \& Vähämaa, 2010). Further, the results of our paper are consistent with a Malaysian government orientation to increase the representation of women on boards of directors to 30 percent.

The findings of our paper may provide input for the policy makers and the regulatory bodies in Malaysia to pay more attentions for shares buyback programs. In addition to being a tool for financial policy, managers may use share buyback to manage earnings and shares price. Our findings also provide implications that support the policy of regulatory bodies to increase the representation of women on the firms' boardroom. It further supports MCCG 2012 regarding reinforcing the independence of the board of directors through evidencing effective role for independent directors in eliminating earnings managements by using accretive share buyback activities. For future research, academicians could demonstrate deeper on nature of women involvements on top management such as independent, executives, chairman and family member. Future studies could also consider the qualities of women representations on decision making through follow qualitative instruments.

\section{References}

Abdul Latif, R., \& Taufil-Mohd, K. N. (2013). Signaling and Substitution Hypotheses in Malaysian Share Repurchases. Management, 3(2), 99-104. https://doi.org/10.5923/j.mm.20130302.06

Adams, R. B., \& Ferreira, D. (2009). Women in the boardroom and their impact on governance and performance. Journal of Financial Economics, 94(2), 291-309. https://doi.org/10.1111/fima.12069.This

Adams, S. M., Gupta, A., \& Leeth, J. D. (2009). Are female executives over - represented in precarious leadership positions? Ritish Journal of Management, 20(1), 1-12. https://doi.org/10.1111/j.1467-8551.2007.00549.x

Amran, N. A., Ismail, N. I. K., Aripin, N., Hassan, N., Manaf, K. B. A., \& Abdullah, S. N. (2014). Women directors involvement in Malaysia. Australian Journal of Basic and Applied 
Sciences, 8(5), 476-482.

Arun, T. G., Almahrog, Y. E., \& Ali Aribi, Z. (2015). Female directors and earnings management: Evidence from UK companies. International Review of Financial Analysis, 39(March), 137-146. https://doi.org/10.1016/j.irfa.2015.03.002

Barua, A., Davidson, L. F., Rama, D. V, \& Thiruvadi, S. (2010). CFO Gender and Accruals Quality. Accounting Horizons, 24(1), 25-39. https://doi.org/10.2308/acch.2010.24.1.25

Betz, M., \& Skepard, J. M. (1989). Gender Differences in Proclivity for Unethical Behavior. Journal of Business Ethics, 8(5), 321-324.

Burnett, B. M., Cripe, B. M., Martin, G. W., \& McAllister, B. P. (2012). Audit quality and the trade-off between accretive stock repurchases and accrual-based earnings management. Accounting Review, 87(6), 1861-1884. https://doi.org/10.2308/accr-50230

Byrnes, J. P., Miller, D. C., \& Schafer, W. D. (1999). Gender differences in risk taking: A meta-analysis. Psychological Bulletin, 367-383. https://doi.org/10.1037/0033-2909.125.3.367

Campbell, K., \& Mínguez-Vera, A. (2008). Gender diversity in the boardroom and firm financial performance. Journal of Business Ethics, 83(3), 435-451. https://doi.org/10.1007/s10551-007-9630-y

Chandren, S. (2016). Review on the double side of earnings management. Pertanika Journal of Social Sciences \& Humanities, 24(4), 1253-1265.

Chandren, S., Ahmad, Z., \& Ali, R. (2015). Corporate governance mechanisms and accretive share buyback to meet or beat earnings per share forecast. International Journal of Business and Society, 16(3), 344-363.

Cheng, Q., \& Warfield, T. D. (2005). Equity incentives and earnings management. The Accounting Review, 80(2), 441-476. https://doi.org/DOI:

Cohen, D. A., Dey, A., \& Lys, T. Z. (2008). Real and accrual-based earnings management in the pre- and post-Sarbanes-Oxley periods. Accounting Review, 83(3), 757-787. https://doi.org/10.2308/accr.2008.83.3.757

Deloitte. (2015). Women in the boardroom: A global perspective. Obtained from http://www2.deloitte.com/sg/en/pages/risk/articles/women-in-the-boardroom.html.

Dittmar, A. (2000). Why Do Firms Repurchase Stock? The Journal of Business, 73(3), $331-355$.

Farrell, K. a., Yu, J., \& Zhang, Y. (2013). What are the characteristics of firms that engage in earnings per share management through share repurchases? Corporate Governance: An International Review, 21(4), 334-350. https://doi.org/10.1111/corg.12029

Farrell, K., Unlu, E., \& Yu, J. (2014). Stock repurchases as an earnings management mechanism: The impact of financing constraints. Journal of Corporate Finance, 25, 1-15. 
https://doi.org/10.1016/j.jcorpfin.2013.10.004

Francis, B., Hasan, I., Park, J. C., \& Wu, Q. (2009). Gender Differences in Financial Reporting Decision-Making: Evidence from Accounting Conservatism. SSRN Electronic Journal. https://doi.org/10.2139/ssrn.1471059

FMT News. (2016). Women on boards: Malaysia shows the way. Obtained from http://www.freemalaysiatoday.com/category/nation/2016/04/20/women-on-boards-malaysia-s hows-the-way/.

Gavious, I., Segev, E., \& Yosef, R. (2012). Female directors and earnings management in high-technology firms. Pacific Accounting Review, 24(1), 4-32. https://doi.org/10.1108/01140581211221533

Graham, J. C., Harvey, C., \& Rajgopal, S. (2005). The economic implications of corporate financial reporting. Journal of Accounting and Economic, 40(1), 3-73.

Gul, F. A., Yu, S., Fung, K., \& Jaggi, B. (2009). Earnings quality : Some evidence on the role of auditor tenure and auditors ' industry expertise \$. Journal of Accounting and Economics, 47(3), 265-287. https://doi.org/10.1016/j.jacceco.2009.03.001

Gunny, K. a. (2010). The relation between earnings management using real activities manipulation and future performance: Evidence from meeting earnings benchmarks. Contemporary Accounting Research, 27(3), 855-888. https://doi.org/10.1111/j.1911-3846.2010.01029.x

Healy, P. M. (1985). The effects of bonus scheme on accounting decisions. Journal of Accounting \& Economics, 7, 85-107. https://doi.org/10.1016/0165-4101(85)90029-1

Hribar, P., Jenkins, N. T., \& Johnson, W. B. (2006). Stock repurchases as an earnings management device. Journal of Accounting and Economics, 41(1-2), 3-27. https://doi.org/10.1016/j.jacceco.2005.10.002

Ittonen, K., \& Peni, E. (2012). Auditor's gender and audit fees. International Journal of Auditing, 16(1), 1-18. https://doi.org/10.1111/j.1099-1123.2011.00438.x

Khazanchi, D. (1995). Unethical behavior in information systems : The gender factor. Journal of Business Ethics, 14(9), 741-749. https://doi.org/10.1007/BF00872327

Krishnan, G. V., \& Parsons, L. M. (2008). Getting to the bottom line: An exploration of gender and earnings quality. Journal of Business Ethics, 78(1-2), 65-76. https://doi.org/10.1007/s10551-006-9314-z

Lam, K. C. K., Mcguinness, P. B., \& Paulo, J. (2013). CEO gender, executive compensation and firm performance in Chinese - listed enterprises. Pacific-Basin Finance Journal, 21(1), 1136-1159.

Liu, Y., Wei, Z., \& Xie, F. (2016). CFO gender and earnings management: Evidence from China. Review of Quantitative Finance and Accounting, 46(4), 881-905. https://doi.org/10.1007/s11156-014-0490-0 
Nielsen, S., \& Huse, M. (2010). Women directors' contribution to board decision-making and strategic involvement: The role of quality perception. Corporate Governance: An International Review, (June 2017). https://doi.org/10.1057/emr.2009.27

Peni, E., \& Vähämaa, S. (2010). Female executives and earnings management. Managerial Finance, 36(7), 629-645. https://doi.org/10.1108/03074351011050343

Powell, M., \& Ansic, D. (1997). Gender differences in risk behaviour in financial decision-making: An experimental analysis. Journal of Economic Psychology, 18(6), $605-628$.

Roychowdhury, S. (2006). Earnings management through real activities manipulation. Journal of Accounting and Economics, 42, 335-370. https://doi.org/10.1016/j.jacceco.2006.01.002

Siagian, F. T., \& Tresnaningsih, E. (2011). The impact of independent directors and independent audit committees on earnings quality reported by Indonesian firms. Asian Review of Accounting, 19(3), 192-207.

Skinner, D. J., \& Sloan, R. G. (2002). Earnings surprises, growth expectations, and stock returns or don't let an earnings torpedo sink your portfolio. Review of Accounting Studies, 7(2-3), 289-312. https://doi.org/10.1023/A:1020294523516

Sun, J., Lan, G., \& Liu, G. (2014). Independent audit committee characteristics and real earnings management. Managerial Auditing Journal, 29(2), 153-172. https://doi.org/10.1108/MAJ-05-2013-0865

Teoh, S. H., Welch, I., \& Wong, T. J. (1998). Earnings management and the long-run market performance of initial public offerings. The Journal of Finance, 53(6), 1935-1974. https://doi.org/10.1111/0022-1082.00079

Teoh, S., Welch, I., \& Wong, T. (1998). Earnings management and the underperformance of seasoned equity offerings. Journal of Financial Economics, 50(1), 63-99. https://doi.org/10.1016/S0304-405X(98)00032-4

Thiruvadi, S., \& Hua-Wei Huang. (2011). Audit committee gender differences and earnings management. Gender in Management: An International Journal, 26(7), 483-498. https://doi.org/10.1108/17542411111175469

Valenti, A. (2008). The Sarbanes-Oxley Act of 2002: Has it Brought about changes in the boards of large U. S . corporations? Journal of Business Ethics, 81(2), 401-412. https://doi.org/10.1007/s10551-007-9503-4

Xie, B., Davidson, W. N., \& Dadalt, P. J. (2003). Earnings management and corporate governance: The role of the board and the audit committee. Journal of Corporate Finance, 9(3), 295-316. https://doi.org/10.1016/S0929-1199(02)00006-8 